\title{
Systematics of Isocarpha (Compositae: Eupatorieae)
}

\author{
David J. Keil \\ Department of Biological Sciences, California Polytechnic State University, \\ San Luis Obispo, California 93407 \\ Tod F. Stuessy \\ Department of Botany, Ohio State University, Columbus, Ohio 43210
}

\begin{abstract}
Isocarpha comprises five species ranging from southern Texas and the Bahamas to northern Peru and northeastern Brazil. The genus belongs in Eupatorieae rather than Heliantheae, but structure of the head of Isocarpha with its elongate, chaffy receptacle is anomalous within Eupatorieae. An hypothesis is presented suggesting the evolutionary derivation of this type of head through formation of floral buds in the axils of the involucral bracts. Generic ties of Isocarpha within Eupatorieae are unclear, but the closest affinities appear to be with Ayapana and relatives.
\end{abstract}

Isocarpha is a small genus of Latin American Compositae occurring principally within Mexico, Central America, the Caribbean, and northern South America. Taxonomic problems at the specific and varietal levels have persisted for many years, but more vexing have been questions of generic, subtribal, and tribal affinities. Isocarpha has been treated as belonging both to Eupatorieae (Robinson and King 1977) and Heliantheae (Stuessy 1977). Part of this difficulty of tribal placement has derived from the unusual conical receptacle and lack of differentiation between involucral and receptacular bracts. These problems suggested the need for a modern revision with focus on reproductive morphology and tribal and generic affinities.

\section{TAXONOMIC History}

Isocarpha was first recognized by Robert Brown (1817) who formed the genus to accommodate two Linnaean species, Calea oppositifolia and Spilanthus atriplicifolius, that were discordant elements in the genera to which they had originally been assigned. Cassini $(1822,1823)$ suggested that Isocarpha be placed in Heliantheae and added two additional species ( $I$. kunthii and I. pyrethraria), both of which we have excluded from the genus.

'Lessing (1830), believing Brown's Isocarpha to be congeneric with Calydermos Lagasca [=Calea L., Heliantheae], described as new his own version of Isocarpha in which he included a new species, I. echioides. This taxon was later transferred by Hemsley (1881) to Ageratum (Eupatorieae). In 1831, Lessing reversed his opinion and merged his own version of Isocarpha with that of Brown and added to it another new species ( $I$. billbergiana). In the same publication (Lessing 1831) he noted that species 
of Isocarpha have styles resembling those of Eupatorium (Eupatorieae). Lessing (1832) placed Isocarpha in "Eupatoriaceae" (=Eupatorieae) in the subtribe Alomieae. De Candolle (1836) treated Isocarpha as a member of Eupatorieae. In the same publication, however, he described a new genus, Dunantia, with two species, D. achyranthes and D. microcephala, and placed this new genus in Heliantheae. Grisebach (1860) recognized that Dunantia achyranthes and Isocarpha oppositifolia were conspecific and reduced Dunantia to a section of Isocarpha.

Gardner (1846) expanded the concept of Isocarpha to include three species from Brazil (I. eupatorioides, I. fastigiata, and I. foliosa), but all three were subsequently transferred to other genera, all members of Eupatorieae. Several additional species were proposed by various other workers during the latter half of the nineteenth and the early part of the twentieth centuries. Altogether fifteen different species names have been validly published in Isocarpha.

\section{Tribal Relationships}

The affinities of Isocarpha have been controversial. Some authors have placed the genus in Heliantheae and others in Eupatorieae. Cassini (1822) was the first to assign Isocarpha to Heliantheae and he was followed by Bentham and Hooker (1873) and by Hoffmann (1890). Lessing (1831) was the first to suggest that Isocarpha be placed in Eupatorieae and he was followed in this by de Candolle (1836). Later workers, however, largely followed the treatments of Bentham and Hooker and of Hoffmann and placed Isocarpha in Heliantheae. B. L. Robinson (1911), the leading authority on Eupatorieae in the early part of the twentieth century, regarded Isocarpha as a member of Heliantheae.

Recent events have brought about a reconsideration of the tribal position of Isocarpha. King and Robinson (1969), as a part of their studies of Eupatorieae, moved Isocarpha from Heliantheae to Eupatorieae. Stuessy (1977), however, retained Isocarpha in Heliantheae, placing it in Galinsoginae near Spilanthes Jacq. Nevertheless, Robinson and King (1977) restated their belief that Isocarpha is a member of Eupatorieae in the "Ayapana group."

The difficulties of assigning Isocarpha to tribe center on the unusual structure of the head. The receptacle is elongate and densely chaffy. The florets are all tubular, fertile, and epappose. Within Heliantheae heads with a high-conic to cylindrical receptacle are not common, but they occur in several genera, e.g., Heliopsis Pers., Ratibida Raf., and Spilanthes Jacq. Heliantheae, as constituted by Bentham and Hooker (1873), comprises plants with chaffy receptacles. Both discoid heads and epappose achenes also occur within the tribe.

The structure of the head of Isocarpha would be anomalous within Eupatorieae, in which receptacles are generally flat to convex although in a few genera, e.g., Ageratum, the receptacle may be conical. Within 
Eupatorieae only the epaleaceous genera Praxelis Cass. and Eupatoriopsis Hieron. approach the extremely elongate receptacle of Isocarpha but they differ from Isocarpha in many other features. Chaffy receptacles are likewise uncommon in Eupatorieae. Discoid heads are the rule, and in this respect Isocarpha fits well. In regard to floral features, as noted first by Lessing (1831), the style branches of Isocarpha are eupatorioid. Also, most Eupatorieae have achenes with a pappus of capillary bristles, but epappose achenes occur sporadically among many members of the tribe.

Based on general architecture of the heads, Isocarpha might appear to fit better within Heliantheae than Eupatorieae. In our examination of the systematic position, however, we have also considered evidence from floral microfeatures, cytology, published reports of chemical studies, and field observations. We examined numerous specimens of Isocarpha as well as its purported relatives in both Heliantheae and Eupatorieae.

King and Robinson presented a group of microfeatures that they believe are useful in differentiating Eupatorieae from Heliantheae (King and Robinson 1970, 1975; Robinson and King 1977; Bohlmann et al. 1977, 1978). These microfeatures are: Style bases in Heliantheae are said to be glabrous whereas those in Eupatorieae are often papillose to pubescent. Style appendages in Heliantheae are typically shorter than the stigmatic area and the reverse is true for Eupatorieae. Cell walls of anther collars of many eupatorioid genera have annular thickenings and cell walls of exothecial (perhaps better described as endothecial, H. Robinson, pers. comm.) layers have nodular thickenings on both axial and transverse walls, and both conditions are said to be unknown in Heliantheae. Anther appendages of Eupatorieae are flat whereas those in Heliantheae are said to be axially folded and medially thickened. Based upon these criteria, Isocarpha appears to be of eupatorioid stock. Three of the five species of Isocarpha have papillose style bases. The style appendages of Isocarpha range from shorter to longer than the stigmatic areas. The cell walls of the anther collars have annular thickenings, the exothecial cells have nodular thickenings on both the axial and transverse walls, and the anther appendages are flat.

Before accepting these microfeatures as evidence of Isocarpha's tribal affinities, however, we carried out an independent evaluation of the conditions reported to occur or not occur in Heliantheae. We surveyed microscope slides of florets of representatives of about seventy percent of the genera included by Stuessy (1977) in Heliantheae. We found that although some of the microfeatures used by King and Robinson appear to represent consistent differences between Eupatorieae and Heliantheae, others do not. The consistent features of Heliantheae include lack of pubescence or papillosity on the style bases, short style appendages, and folded or keeled, medially thickened anther appendages. However, we found annular thickenings on essentially all cell walls of anther collars in Pinillosia berteroi (Sw.) Urban and on at least some anther collar cell walls in some species of Actinospermum Ell., Baileya Harv. \& Gray, Balti- 
mora L., Coreocarpus Benth., Dahlia Cav., Goldmanella Greenm., Jaegeria H.B.K., Riencourtia Cass., and Staurochlamys J. G. Baker. Exothecial cells with nodular thickenings on both axial and transverse walls occur in Dahlia, Pinillosia Ossa ex DC., and in all eight genera of Ambrosiinae (including Parthenice A. Gray and Parthenium L.).

This survey led us to the conclusion that presence of any one of the eupatorioid features in Isocarpha is by itself not conclusive evidence of its tribal affinity. Rather, the convincing factor is the presence in Isocarpha of a suite of features that occur together in many members of Eupatorieae and that are not known to occur together in any member of Heliantheae.

Evidence of $n=10$ from chromosome counts from our own studies (six new counts of $n=10$ reported here in Isocarpha oppositifolia var. achyranthes; see asterisks in list of representative specimens) and from those of King et al. (1976) and Jansen and Stuessy (1980) support placement of Isocarpha in Eupatorieae. The base number, $x=10$, is very common in Eupatorieae (King et al. 1976; Robinson and King 1977) and relatively uncommon in Heliantheae (Stuessy 1977).

The morphological and cytological data suggest that the similarity (noted by Stuessy 1977) between Isocarpha and the helianthoid genus Spilanthes (including Acmella A. Rich.) is an example of convergent evolution. These last two genera (until recently united as Spilanthes; Jansen 1979,1981 ) have conical chaffy receptacles, and some taxa of Acmella have eradiate white-flowered heads. The appearance of a close relationship has persisted since the time of Linnaeus. Recent monographic studies of Acmella and Spilanthes by Robert Jansen in the laboratory of the junior author, however, have confirmed that these genera differ from Isocarpha in many features of the involucral bracts, receptacular bracts, florets, and achenes. The chromosomal base number for Spilanthes is $x=16$ and for Acmella, $x=13$. With this apparent tie to Heliantheae weakened, Isocarpha slips off more easily into Eupatorieae.

Chemical analyses of terpenoids of Isocarpha atriplicifolia and I. oppositifolia have provided some additional evidence supporting a relationship of Isocarpha to Eupatorieae (Bohlmann et al. 1977, 1978). Although none of the compounds isolated to date from Isocarpha represents a chemical group unique to Eupatorieae, the benzofurans represent a type widespread in Eupatorieae and comparatively rare in Heliantheae. None of these compounds has thus far been isolated from any of the genera suggested by Stuessy (1977) to be close relatives of Isocarpha. Bohlmann et al. (1978) did not indicate, however, how many of these putative relatives had been checked for these compounds.

\section{Structure of the Head}

Determination of generic relationships of Isocarpha within Eupatorieae depends to a considerable extent upon interpretation of the unusual 
structure of the capitulum. Isocarpha has an elongate receptacle to which are attached numerous spirally imbricate bracts. In one species, I. oppositifolia, each bract subtends an individual floret, but in the other species a few of the outermost bracts are sterile. Briquet (1917) considered the involucral bracts and receptacular bracts of Isocarpha to differ in form and structure, but we have observed no structural differentiation. A determination of which bracts comprise the involucre and which should be called receptacular pales is arbitrary. The outer bracts are often slightly more foliaceous and somewhat broader than the inner bracts, but the change from one type to the other is gradual. Additionally, the uppermost bracts of the peduncle are nearly identical to the outer bracts of the head.

The majority of taxa in Eupatorieae have flat to weakly convex receptacles that lack receptacular pales. Involucres in Eupatorieae range from a single whorl of subequal or equal bracts as in Piqueria to a subimbricate assemblage of more-or-less equal bracts to a very strongly imbricate series of numerous bracts of varying lengths. The florets are often very numerous and the top of the head at anthesis is generally flat or slightly rounded, not elongate as in Isocarpha.

Chaffy receptacles are usually considered to be a primitive feature in Compositae (Cronquist 1955, 1977; Carlquist 1976; Wagenitz 1976). Carlquist (1976, p. 471) opined that "intergradation of involucral bracts into receptacular bracts would be expected to be a primitive feature in Asteraceae." If Isocarpha with its lack of differentiation between involucral and receptacular bracts is considered to be primitively paleaceous, then the genus stands far removed from other genera of Eupatorieae.

Robinson and King (1977) indicated that they consider the chaffy receptacle of Isocarpha to be a derived feature, and that the ancestral taxon that gave rise to Isocarpha had a naked receptacle. They proposed (Robinson and King 1977, p. 443) that genera or species in Eupatorieae with chaffy receptacles mostly "seem to represent an erratic capacity in the Eupatorieae for revival of this suppressed structure." This explanation implies that in the origin of Isocarpha receptacular bracts have developed among the florets of an epaleaceoûs ancestral head. Although this hypothesis is a possibility, it does not explain well the high conical receptacle of Isocarpha nor the very reduced involucre with few or no sterile bracts.

The position of Isocarpha in Eupatorieae suggested by Robinson and King (1977) is within a group of genera named the "Ayapana Group" [recently validated by King and Robinson (1980a) as Ayapaninae but without mention of included genera except the type; the recently described genus Parapiqueria apparently also belongs in this subtribe (King and Robinson 1980b)]. Assuming this assignment to be correct, it would be difficult to derive the head structure of Isocarpha by the proposed de novo mechanism for the origin of pales on the receptacle. Other genera assigned to the Ayapana group have subimbricate, multiseriate, tubular to campanulate involucres. Receptacles are flat or nearly so in all but 
Lepidesmia squarrosa Klatt. If we imagine a head of Isocarpha without its receptacular chaff, the resulting hypothetical plant does not have an involucre resembling that of any member of the Ayapana group. If, on the other hand, we imagine the insertion of receptacular bracts among the florets of any member of the Ayapana group, the result is also very far from Isocarpha.

We offer an alternate hypothesis for the origin of the chaffy receptacle of Isocarpha. We suggest that the ancestral stock from which Isocarpha arose had an imbricate or subimbricate involucre and relatively few florets per head. Extant species with a similar condition can be found in several different genera scattered throughout Eupatorieae and we have chosen Condylidium iresinoides (fig. 1A), a member of the Ayapana group, as a model (not regarded as ancestral, only as an example for our hypothesis). Condylidium iresinoides has a subimbricate involucre with the bracts attached in a regular spiral pattern to the axis of the head. The actual receptacular area to which the florets are attached is slightly convex. Condylidium heads usually have only five florets and each floret is subtended by one of the uppermost involucral bracts. There are no re-

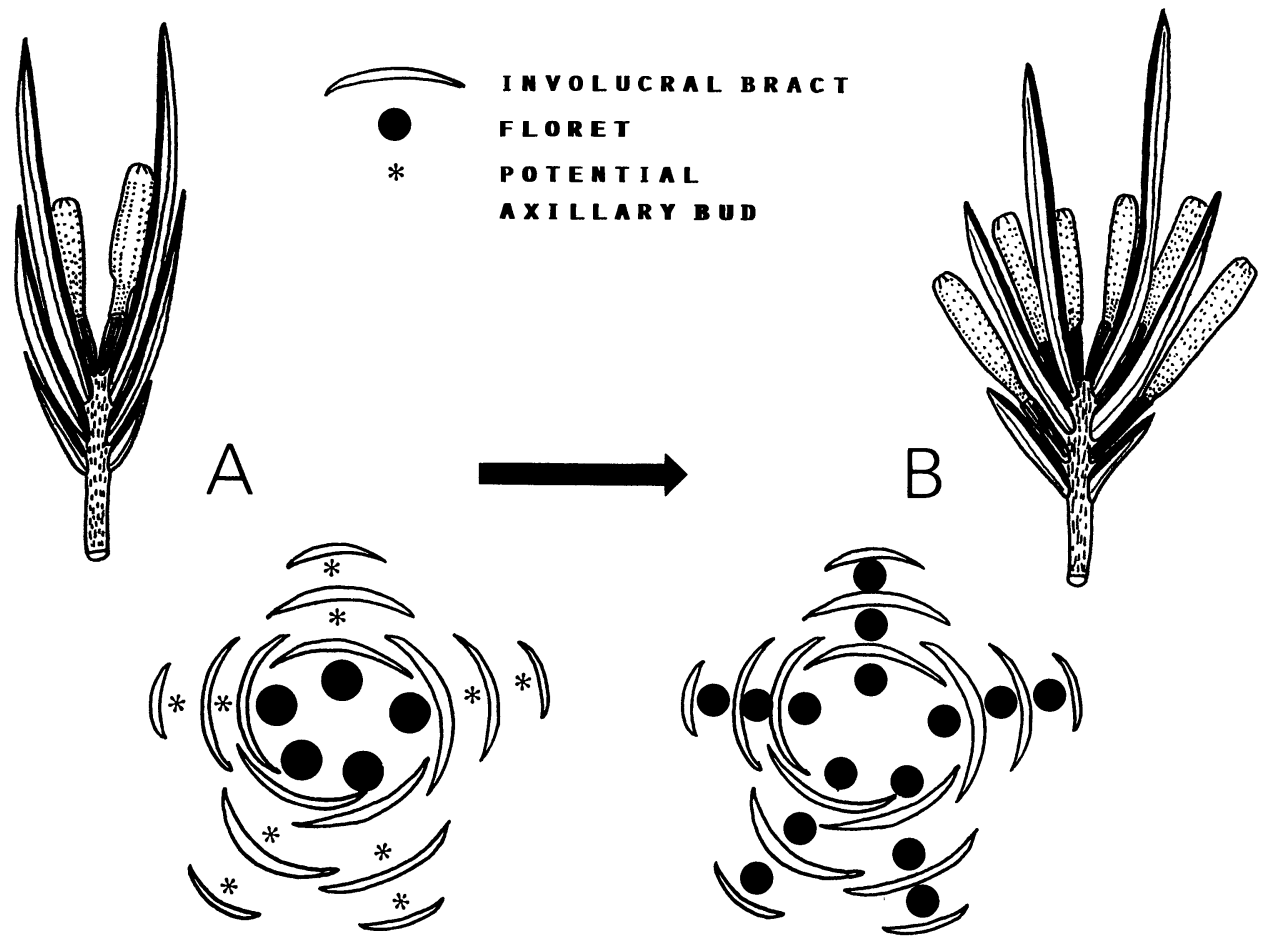

FIG. 1. Hypothetical evolutionary origin, showing longitudinal (pappus omitted) and diagrammatic views, of the head of the precursor to Isocarpha (B) from a Condylidiumlike ancestor (A; C. iresinoides (H.B.K.) King \& Robinson). 
ceptacular bracts distributed among the florets. The axis of the head below the level of the florets is elongate.

Our model for the origin of the head of Isocarpha hypothesizes a potential for formation of floral buds in the axils of the involucral bracts. In Compositae, buds generally fail to develop in the axils of all but the innermost series of involucral bracts (Philipson 1947, 1948, 1953). Philipson (1953, pp. 402-403) indicated that "... for a brief period in the growth of the axis no part of the apical meristem becomes detached as the primordium of a lateral bud. Both before, when foliage is being formed, and after, when the receptacular scales are appearing, axillary buds are formed." If, however, the potential for development of floral buds in the axils of the involucral bracts of a Condylidium-like head is released, the head structure of Isocarpha would immediately be approximated. Instead of only the uppermost bracts subtending florets as in Condylidium iresinoides, all the bracts would subtend florets (fig. 1B). Because the involucral bracts are already attached in a spiral pattern to an elongate axis, no change from a flat to a conical receptacle need be envisaged. No interpolation of bracts among florets need be hypothesized. The lack of distinction in the head of Isocarpha between involucral bracts and receptacular bracts is explained by our model because the bracts all originated as homologous members of an involucre. The head derived in this manner might initially be smaller than that of any extant species of Isocarpha, but evolutionary increase in size of Compositae heads has been supposed to occur frequently (Stebbins 1967). All that is required is for the pattern of involucral bracts subtending florets to be maintained as the indeterminate axis of the head elongates.

The mechanism of origin of the head of Isocarpha discussed above also may have resulted in the parallel origin of the head structure of Lepidesmia squarrosa (Eupatorieae), a structural similarity first noted by B. L. Robinson (1911). In this species only the uppermost of the latent buds have developed into florets. Buds in the axils of the lowermost bracts of the head are also active, however. These lower buds give rise to head primordia resulting in the formation of dense cymose clusters of slender heads. The tendency of outer bracts to subtend head primordia rather than floret primordia is also found sometimes in Isocarpha oppositifolia in which the uppermost peduncular bracts (spatially removed from the lowermost bracts by 1-2 $\mathrm{mm}$ ) subtend heads, the result being cymosely aggregated capitula terminating the peduncles (see fig. 5B).

\section{Generic Affinities}

Robinson and King (1977) suggested that within Eupatorieae Isocarpha belongs in the "Ayapana Group," which contains: Alomiella King \& Robinson, Ayapana Spach, Ayapanopsis King \& Robinson, Condylidium King \& Robinson, Gongrostylis King \& Robinson, Gymnocondylus King \& Robinson, Heterocondylus King \& Robinson, Isocarpha, Monogereion Barroso 
\& King, Parapiqueria King \& Robinson, and Polyanthina King \& Robinson. The monotypic Lepidesmia was treated as a synonym of Ayapana by Robinson and King (1977), but Harold Robinson (pers. comm.) now believes it to be a distinct genus. The group is characterized as having subimbricate, persistent involucres, usually slender style branches, smooth corolla lobes, usually annulated anther collars, and enlarged, sometimes "hirsute" style bases. Several of the genera have the basal tier of cells of the carpopodium prominently enlarged.

In most of the features listed above, Isocarpha fits relatively well with members of the Ayapana group, but it differs in some respects. As indicated in the previous section of the paper, differences in involucral structure between Isocarpha and the other genera may be less than first appearances would indicate. Style branches of Isocarpha are not as elongate as in some other genera, but they are similar to those of Lepidesmia. Structure of the anther collar and of the style base also fits well in the Ayapana group. In Isocarpha, all cells of the carpopodium are small and this sets the genus apart from the central generic complex of the Ayapana group. The chromosomal base number of $x=10$ for Isocarpha is the same as that for other genera of the Ayapana group (Robinson and King 1977): Ayapana (also $n=17,18$ ), Condylidium, and Polyanthina (also $n=$ $12 \pm 1)$. A count of $n=$ ca. 20 for Heterocondylus very likely represents a tetraploid based on $x=10$. The remaining genera are cytologically unknown.

We have compared Isocarpha with members of a variety of other informal groups and subtribes as recognized by Robinson and King (1977). In addition to the Ayapana group, the only other possible close relatives seem to be the Gyptis group [validated recently as Gyptidinae but without list of included genera; King and Robinson 1980a] or Piqueriinae. A close relationship to any other groups or subtribes seems much less likely. The chromoscmal base number of $x=10$ would not exclude Isocarpha from either the Gyptis group or Piqueriinae. A possible link between Isocarpha and these groups is the presence of papillosity on the corolla lobes of I. fistulosa and I. megacephala. Papillose corolla lobes are common in both the Gyptis group and Piqueriinae but absent in most of the $A y$ apana group. Unfortunately, this differentiation does little for placement of Isocarpha, because corolla lobes in the remaining species are either smooth or minutely roughened and the direction of evolution of this character is unknown. The papillose style bases of some species of Isocarpha would be somewhat atypical in the Gyptis group or in Piqueriinae.

An examination of vegetative features suggests a placement of Isocarpha in or near the Ayapana group. Leaves of species of Isocarpha have tapering wings on their petioles and one species, I. atriplicifolia, has clasping auricles at the base. Several genera of the Ayapana group have similar winged petioles and some Ayapana species also have basal auricles. This is not true in either the Gyptis group or in Piqueriinae.

Although we believe that the closest living relatives of Isocarpha are 
probably members of the Ayapana group, the relationship appears somewhat distant. Isocarpha apparently has been distinct for a sufficiently long time that it now occupies a broad geographical range with considerable disjunctions. The diversity of corolla forms (cylindrical and ampliate) within this small genus is also a suggestion of marked evolutionary diversification. Certainly within the Ayapana group, Isocarpha is peripheral to the main line of evolutionary change.

\section{TAXONOMY}

IsOCARPHA R. Br., Trans. Linn. Soc. London 12:110. 1817.-Type: Calea oppositifolia L. $\equiv$ Isocarpha oppositifolia (L.) Cass.

Dunantia DC., Prodr. 5:627. 1836.-TYPE: Dunantia achyranthes DG. $\equiv$ Isocarpha oppositifolia (L.) Cass. var. achyranthes (DC.) Keil \& Stuessy. Annual or perennial herbs. Leaves opposite below, often alternate above, simple, sessile or with winged petioles, subglabrous to densely short-pubescent, punctate-glandular at least abaxially. Peduncles terminal or axillary, 1-12-headed, bracteolate below the heads with 1-8 narrow scale- or leaf-like bractlets. Heads discoid, ovoid, 60-200-flowered with a high-conic to columnar, densely chaffy receptacle about $2 / 3$ to $3 / 4$ the length of the head. Involucral and receptacular bracts not differentiated, the outermost bracts usually sterile, the remainder all subtending florets, all linear to ovate, carinate with 1-6 slender ribs, ciliolate and variously pubescent at least at the apex. Florets all perfect. Corollas white, pink, or purple, regular, 5-lobed, proportion of tube to throat variable, externally glabrous or stipitate-glandular, internally glabrous, on the inner surface of the lobes smooth or papillose. Stamens included; cells of the anther collar with annular thickenings; exothecial cells with nodular thickenings on both transverse and axial walls; terminal appendage deltoid, flat, entire to slightly erose, slightly constricted at the base. Style with a basal node (except in I. megacephala); the style base and node glabrous to slightly papillose or short-pubescent; style branches slender, the papillose appendage as long as or longer than the stigmatic area. Achenes 5-sided, blackish, oblong to narrowly ovoid, at the base tapering; epappose, glabrous or, in I. atriplicifolia, puberulent with basally forked hairs; carpopodium oblique, the cells all small. Chromosome base number: $x=10$.

\section{KEY TO THE TAXA OF ISOCARPHA}

Leaves with auriculate-clasping bases; achenes puberulent.

Peduncles, involucral bracts, and outer receptacular bracts densely glandular with both stipitate and sessile glands; non-glandular hairs few or absent ..

Peduncles, involucral bracts, and outer receptacular bracts puberulent to short- 
pilose with non-glandular hairs and punctate-glandular; stipitate-glandular hairs few or absent.

Involucral bracts and outer receptacular bracts ovate or broadly lanceolate,

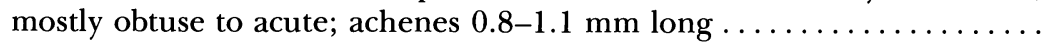
$\ldots \ldots \ldots \ldots \ldots \ldots \ldots \ldots \ldots \ldots \ldots \ldots \ldots \ldots \ldots \ldots$ 1b. I. atriplicifolia var. wrightii

Involucral bracts and outer receptacular bracts lanceolate to oblong, mostly

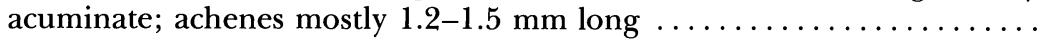
$\ldots \ldots \ldots \ldots \ldots \ldots \ldots \ldots \ldots \ldots \ldots$ 1a. I. atriplicifolia var. atriplicifolia

Leaves tapering to stems without basal auricles; achenes glabrous.

Corolla cylindrical, not well-differentiated into tube and throat; involucral bracts with 4-6 longitudinal ribs $\ldots \ldots \ldots \ldots \ldots \ldots \ldots \ldots \ldots \ldots \ldots \ldots \ldots \ldots \ldots \ldots \ldots$ I. megacephala

Corolla gradually or abruptly ampliate, the tube and throat well-differentiated; involucral bracts with 1-2 longitudinal ribs.

Leaves mostly opposite; involucral bracts with 2 conspicuous ribs, stiff, apiculate, whitish or stramineous; corolla gradually ampliate.

Leaves linear to narrowly oblong or narrowly elliptic, less than $1 \mathrm{~cm}$ wide; sometimes with axillary fascicles; heads mostly $6 \mathrm{~mm}$ tall or less, densely cymose $\ldots \ldots \ldots \ldots \ldots \ldots \ldots \ldots \ldots \ldots$. $\ldots$ a. I. oppositifolia var. oppositifolia

Leaves oblong-elliptic to lanceolate or ovate, usually at least the lower over $1 \mathrm{~cm}$ wide, usually without axillary fascicles; heads usually $6-10 \mathrm{~mm}$ tall, solitary or 2-7 in' cymose clusters ... 4b. I. oppositifolia var. achyranthes

Leaves mostly alternate; involucral bracts with 1-2 inconspicuous ribs, soft, acute to acuminate, pubescent with purplish hairs; corolla abruptly ampliate.

Heads mostly solitary; peduncles fistulose ................ 3. I. fistulosa Heads mostly in clusters of 3-5; peduncles cylindrical, not fistulose ......

2. I. microcephala

\section{IsOcARPHA R. Br. sect. IsOcarpha}

Isocarpha R. Br. sect. Dunantia (DC.) Griseb., Flora Brit. W. Ind. 376. 1864.-Dunantia DC., Prodr. 5:627. 1836.-TyPE: Dunantia achyranthes DC. $\equiv$ Isocarpha oppositifolia (L.) Cass. var. achyranthes (DC.) Keil \& Stuessy.

Isocarpha R. Br. sect. Spilanthodia Griseb., Flora Brit. W. Ind. 377. 1864.TYPE: Isocarpha atriplicifolia (L.) R. Br. ex DC.

Corollas with well-defined tubes and throats; styles with a basal node, deciduous from the nectary when the corolla abscises.

1. Isocarpha atriplicifolia (L.) R. Br. ex DC., Prodr. 5:106. 1836. This combination has been universally attributed to Brown (1817), who included Spilanthus atriplicifolius L. in his new genus, Isocarpha, but he did not explicitly propose the combination. De Candolle (1836) was apparently the first to use the combination and he attributed it to Brown.

Fibrous-rooted erect or decumbent annual or sometimes perennial 
herbs 1-12 dm tall, sometimes rooting at lower nodes. Stems one to several from the base, glandular-puberulent to short-villous, often somewhat glabrate with age, sometimes punctate-glandular; branches ascending to spreading at angles of $30-80^{\circ}$. Leaves opposite below, alternate above, petiolate; petioles $0.5-5.0 \mathrm{~cm}$ long, winged from the base of the blade, abruptly expanded to an auriculate clasping base, at nodes with opposite leaves with the auricles sometimes connate around the stem; blades rhombic-ovate to lanceolate, $1-10 \mathrm{~cm}$ long, $0.5-5.0 \mathrm{~cm}$ wide, diminishing above to foliaceous bracts, mostly 3-veined from near the summit of the petiole, apically mostly acute to long-acuminate, basally obtuse to acuminate, tapering to the petiolar wing, margins shallowly crenatedentate to entire, abaxially sparsely to densely puberulent and punctateglandular, adaxially subglabrous to densely puberulent. Peduncles 1-5 $\mathrm{cm}$ long, one-headed, several to many borne alternately on bracteate, sympodial, often weakly scorpioid axes terminating the main stems and branches, glandular-puberulent to densely short-villous; peduncular bractlets $0-8$, usually the lower leaf-like and the upper reduced to linear scales resembling the outer bracts of the heads. Heads ovoid, 5-10 $\mathrm{mm}$ tall, 4-7 mm diam., basally rounded to truncate, apically subacute. Involucre with 2-7 sterile outer bracts surrounding the outermost fertile bracts; bracts greenish, oblong to ovate, $2-3.5 \mathrm{~mm}$ long, 0.7-1.1 $\mathrm{mm}$ wide, obtuse to acuminate, carinate with a single central rib or a pair of parallel ribs, somewhat reticulate-veined on either side of the ribbed area, glandular puberulent to densely short-pilose, sometimes subglabrous, usually sparsely to densely punctate-glandular, the margins ciliolate with glandular or eglandular hairs, especially distally. Inner receptacular bracts proximally stramineous to hyaline, distally greenish to brownish, oblong-oblanceolate, $2.1-3.5 \mathrm{~mm}$ long, $0.5-0.8 \mathrm{~mm}$ wide, obtuse to acuminate, glandular or short-pilose over the apical half or sometimes over the entire abaxial surface, often ciliolate distally. Florets about equaling the length of the receptacular bracts; corollas white, 1.4-2.5 $\mathrm{mm}$ long, tube $0.4-0.7 \mathrm{~mm}$ long, throat gradually ampliate, $0.8-1.3 \mathrm{~mm}$ long, lobes triangular, $0.2-0.5 \mathrm{~mm}$ long, glabrous to sparsely puberulent externally with multicellular glandular hairs; anthers $0.5-1.25 \mathrm{~mm}$ long; stylar node ellipsoid, smooth to minutely papillose, style branches shortly exserted beyond the apex of the corolla. Achenes blackish, oblong to ellipsoid, 0.9-1.5 mm long, puberulent with basally forked double hairs, abruptly narrowed to a contorted substipitate base bearing the carpopodium at nearly a right angle to the axis of the achene; carpopodium cylindrical to hemispherical, whitish, larger in diameter than the achenial base. Chromosome number: $n=10$.

Isocarpha atriplicifolia occurs in continental North America from southern Mexico to Costa Rica, in the Caribbean area in Cuba, the Dominican Republic, and Trinidad, and in South America in Colombia, Venezuela, and-Brazil (figs. 2 and 3). Within this broad range are three weakly differentiated varieties, which have been treated in recent floras as separate species. Blake (1926) and Alain (1963) recognized the Cuban pop- 


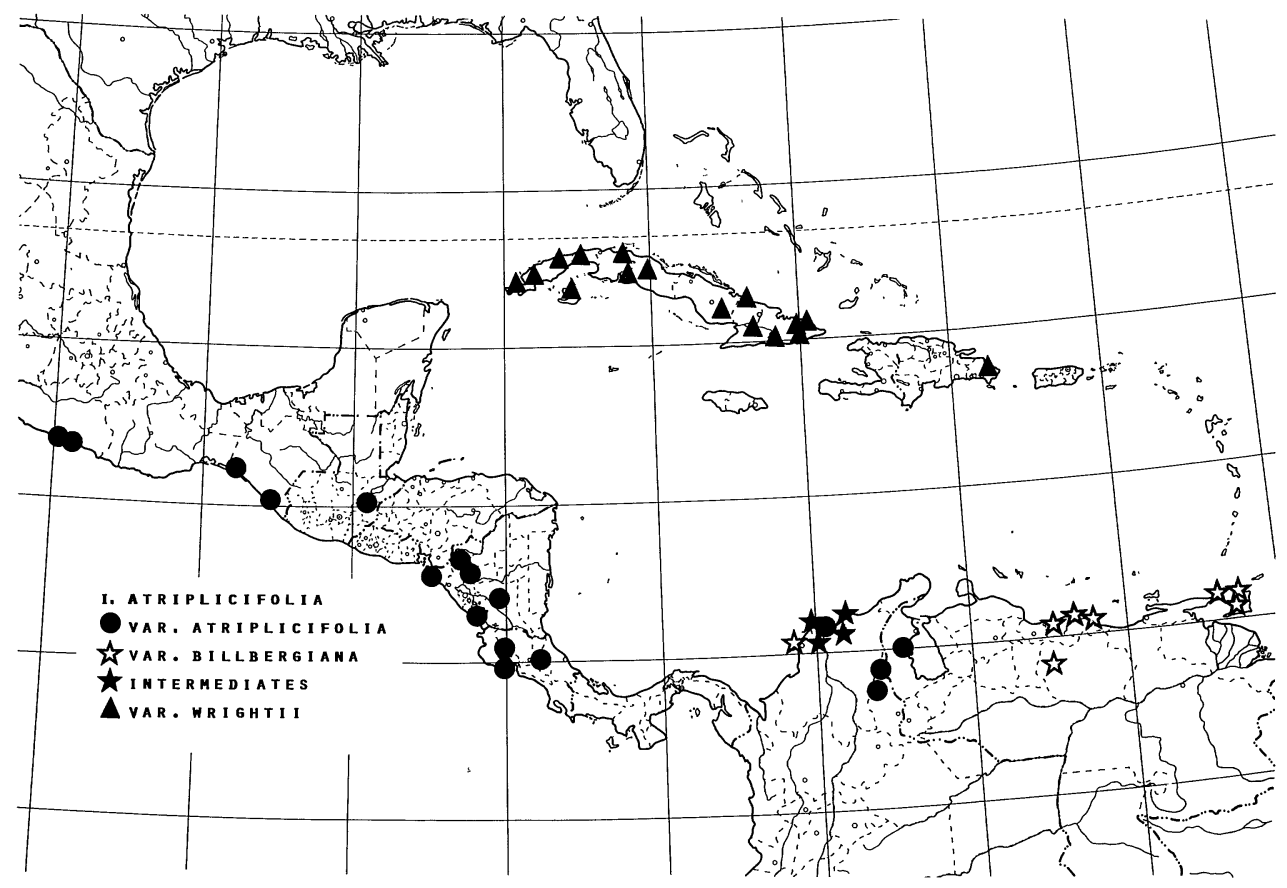

Fig. 2. Distribution of Isocarpha atriplicifolia (two collections from northeastern Brazil are shown in figure 3 ).

ulations as Isocarpha cubana S. F. Blake, and Aristeguieta (1964) listed both I. atriplicifolia and I. billbergiana Less. for Venezuelan populations. We have chosen to recognize these plants at the varietal level for several reasons. All three taxa have extremely similar vegetative morphology and show parallel patterns of variation. The features that distinguish the populations are largely quantitative and overlap occurs. Plants possessing the pubescence of I. atriplicifolia and the floral dimensions of I. billbergiana occur in Colombia (fig. 2). The Trinidad populations have the pubescence and bract types characteristic of I. billbergiana but the floral dimensions approach those of I. cubana. The degree of separation of the three taxa is much narrower than the separations among any of the other species of Isocarpha.

1a. Isocarpha ATriplicifolia (L.) R. Br. ex DC. var. ATriplicifoliaBidens atriplicifolia L., Cent. 2. pl. 30. 1756. Spilanthus atriplicifolius (L.) L., Syst. Nat., 12th ed. 3:236. 1768.-Calydermos atriplicifolius (L.) Spreng., Syst. Veget. 3:457. 1826.-TYPE: "America meridionali," P. Miller s.n. (holotype: LINN, IDC microfiche 177. 553:III.4!; isotype: BM!; photograph: OS!).

Isocarpha alternifolia Cass., Dict. Sci. Nat. 24:19. 1822, nom. superfl. based on type of Bidens atriplicifolia L.

Isocarpha amplexicaulis Robins. ex. C. F. Baker, West. Amer. Pl. 2:21. 


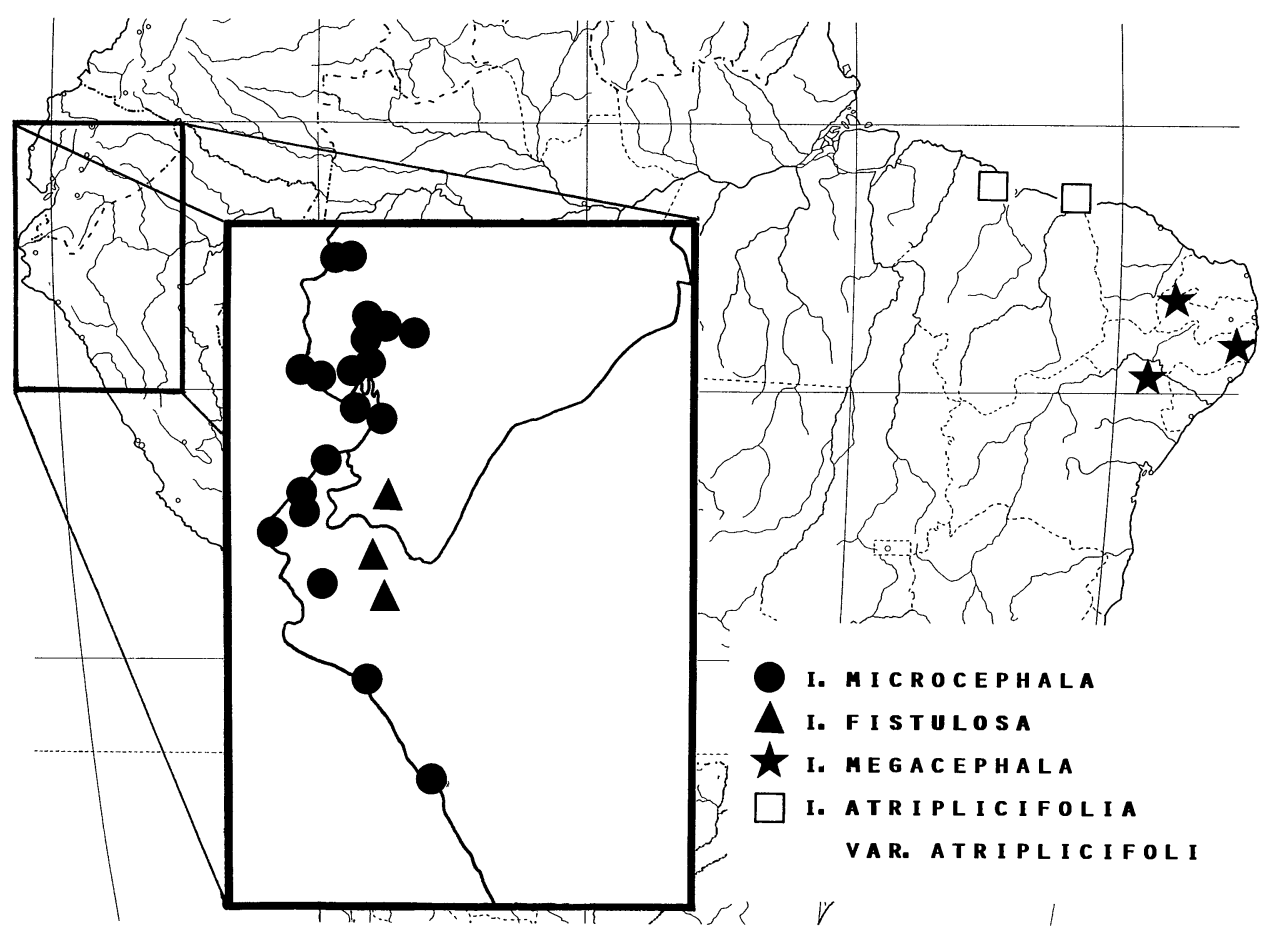

FIG. 3. Distributions of Isocarpha atriplicifolia var. atriplicifolia, I. fistulosa, I. megacephala, and I. microcephala.

1903, nom. nud., based on the following specimen: Nicaragua, Chinandega, Realejo, 16 Jan 1903, C. F. Baker 2098 (GH!).

Involucral bracts and outer receptacular bracts 2.5-3.0 $\mathrm{mm}$ long, lance-oblong, acute to acuminate, usually 2-keeled, puberulent with simple hairs and punctate-glandular, ciliolate with mostly eglandular hairs. Inner receptacular bracts $2.5-3.5 \mathrm{~mm}$ long, acute. Corollas $1.4-2.1 \mathrm{~mm}$ long (rarely to $2.5 \mathrm{~mm}$ long in some Colombian plants), the throat 0.8 $1.1(-1.3) \mathrm{mm}$ long. Achenes (1.0-) 1.2-1.5 mm long. Chromosome number: $n=10$.

Isocarpha atriplicifolia var. atriplicifolia occurs from the southeastern Mexican states of Guerrero and Chiapas to Costa Rica and in northern Colombia and Venezuela with outlying populations in northeastern Brazil in the states of Maranhão and Piaui (figs. 2 and 3). This variety occurs in moist to seasonally dry open areas in savannas, dry woodlands, roadsides, pastures, etc., to $1100 \mathrm{~m}$. These plants have been very infrequently collected in the northern part of their range.

Representative specimens. BrazIL. Maranhão, Perizes, Black et al. 5416507 (NY): Piaui, Ilha de Santa Isabel, Sucre et al. 10278 (US). Colombia. Norte de Santander, Ocana, Schlim 1067 (F). Costa Rica. Guanacaste, Nicoya, Pittier s.n. (F, GH, US); Heredía, San Fran- 
cisco de Heredía de San Joaquin, Brenes s.n. (DS). Guatemala. Zacapa, ca $4 \mathrm{~km} \mathrm{NNW}$ of Zacapa, King 7376 (US). Mexico. Chiapas, Las Garzas, Matuda 2705 (F, GH, MEXU, MICH, MO, NY, UC, US); Guerrero, Acapulco and vicinity, Palmer 534 (DS, F, GH, MO, NY, US). Nicaragua. Chontales, $2 \mathrm{~km} \mathrm{~S}$ of Acoyapa, Seymour 1786 (F, MICH, MO, NY, UC); Esteli, $15 \mathrm{~km}$ N of Esteli, Williams and Molina 20208 (F, NY, US). Venezuela. Zulia, between San José y Alturitas, Aristeguieta and Montoya 2111 (F).

1b. IsOcARPha ATRIPLicifolia (L.) R. Br. ex DC. var. Wrightil Griseb., Cat. Pl. Cub. 156. 1866.-Lectotype (here chosen): Cuba, Pinar del Río, Hacienda de Bartolo near Baja $\left[22^{\circ} 35^{\prime} \mathrm{N}, 84^{\circ} 07^{\prime} \mathrm{W}\right]$ to Nombre de Dios [22 $35^{\prime} \mathrm{N}, 84^{\circ} 0^{\prime} \mathrm{W}$ ], 27-29 Mar 1863, C. Wright 2858 (GOET!; isotypes: GH! GOET! $\mathrm{K}$ ! MO!; photograph of $\mathrm{K}$ isotype: OS!). Two sheets of Wright 2858 are at GOET, both of which have writing in Grisebach's own hand; the most complete specimen has been selected as the lectotype. Most specimens of Wright 2858 bear incomplete or inexact location data. All apparently were distributed as one gathering and we have considered them as such in compiling the location data above.

Isocarpha cubana S. F. Blake, Contr. U.S. Natl. Herb. 22:613. 1934.Type: Cuba, Isle of Pines, near Nueva Gerona, 19 Dec 1903, $A . H$. Curtiss 246 (holotype: US!; isotypes: F! GH! K! M! MO! NY!).

Involucral bracts and outer receptacular bracts $2-2.5 \mathrm{~mm}$ long, lanceolate to ovate, obtuse to acute, usually one-keeled, puberulent with simple hairs and punctate-glandular, very short-ciliolate with mostly eglandular hairs. Inner receptacular bracts 2.1-2.5 mm long, obtuse or apiculate. Corollas 1.4-1.9(-2.2) $\mathrm{mm}$ long, the throat $0.8-1.0(-1.4) \mathrm{mm}$ long. Achenes 0.8-1.1 mm long. Chromosome number unknown.

Isocarpha atriplicifolia var. wrightii is restricted to Cuba, the Isle of Pines, and the Dominican Republic (fig. 2). It is a common, somewhat weedy plant of low-lying stream banks, swamps, savannas, roadsides, and cultivated fields.

Representative specimens. CuBA. Camaguey, vicinity of La Gloria, Shafer 348 (F, NY, US); Havana, near Batabano, León 14757 (NY); Isle of Pines, Santa Fé, Britton et al. 15187 (NY, US); Las Villas, Cienguita, Combs 666 (F, GH, MO, NY, US); Oriente, Paso Estancia, Shafer 1565 (F, NY, US); Pinar del Río, Laguna Jovero and vicinity, Shafer 10737 (MO, NY, US). Dominican RePublic. Seybo, Laguna Ojo del Rancho, Ekman 12121 (A, F, GH, LL, NY, US).

1c. Isocarpha atriplicifolia (L.) R. Br. ex DC. var. billbergiana (Less. in Schlecht. \& Cham.) Keil \& Stuessy, comb. et stat. nov.-Isocarpha billbergiana Less. in Schlecht. \& Cham., Linnaea 6:405. 1831.-TYPE: Colombia, Bolivar, Isla de Tierra Bomba near Cartagena, Jan-Feb 1826, I. Billberg 177 (holotype: B, destroyed during World War II; 
photographs: F! GH! NY!; isotype, here designated as lectotype: P!; photograph: OS!).

Involucral bracts $2.4-3.5 \mathrm{~mm}$ long, lance-oblong, acuminate to longacuminate, usually 2-keeled, densely glandular-puberulent and punctateglandular, margins ciliolate with mostly glandular hairs. Inner receptacular bracts $2.4-3.3 \mathrm{~mm}$ long, acuminate. Corollas (1.5-) $1.8-2.5 \mathrm{~mm}$ long, throat (0.9-) 1.0-1.5 mm long. Achenes 1.1-1.5 mm long. Chromosome number unknown.

Isocarpha atriplicifolia var. billbergiana occurs from northern Colombia to northeastern Venezuela and Trinidad (fig. 2). In Colombia and Venezuela populations intermediate between var. billbergiana and var. atriplicifolia are common (e.g., Romero-Castañeda 7243, Smith 678). Plants of var. billbergiana occur in damp open areas, swamps, riverbanks, etc., up to at least $500 \mathrm{~m}$.

Representative specimens. Colombia. Magdalena, Ciénaga (near Aguacoca), Romero-Castañeda 7243 (NY, US), Santa Marta, Smith 678 (F, GH, LL, MICH, MO, NY, TEX, UC, US). TRINIdAd. Blanchisseuse Road above Verdant Vale, Broadway 5529 (LL, MO, UC). Venezuela. Aragua, between Maracay and Mariana, Alston 5693 (NY, US); Sucre, vicinity of Cristobal Colón, Broadway 91 (GH, NY, US).

2. Isocarpha microcephala (DC.) S. F. Blake, Proc. Biol. Soc. Wash. 39:144. 1926.—Dunantia microcephala DC., Prodr. 5:627. 1836.TyPE: "Mexico," T. Haenke s.n. (holotype: G-DC; photographs: F! GH! NY! TEX! US!; IDC microfiche 800. 693:III.3!; isotype: P!; photographs: GH! OS! US!). As noted by Blake (1926), the type is undoubtedly mislabeled as to origin, because this species is not known from Mexico. Haenke probably collected the specimens near Guayaquil, Ecuador, where he botanized on the Malaspina expedition from 29 Sep-1 Nov 1790 (Cutter 1977; in litt.).

Isocarpha divaricata Benth., Bot. Voy. Sulphur 110. t. 41. 1845.-TYPE: Ecuador, Guayas, Isle of Puna, near Guayaquil, Sep 1836, G. W. Barclay 408 (holotype: BM!; fragment: US!; photograph: OS!). Three collectors from the Sulphur expedition (Barclay, Hinds, and Sinclair) obtained this species at Guayaquil. The specimens of Hinds and Sinclair are deposited at K, and that of Barclay at BM. Because all the collections from the expedition used by Bentham for the entire work are presumably at BM (Stafleu and Cowan 1976), the Barclay collection is regarded as the holotype.

Isocarpha blepharolepis Greenm., Publ. Field Columbian Mus., Bot. Ser. 2:347. 1912.-Type: Peru, Piura, Somate, 18 Nov 1910. C. H. T. Townsend 825 (holotype: US!; photographs: F! GH! MO!; isotype: $\mathrm{F}$ !).

Fibrous-rooted or tap-rooted annual or sometimes apparently perennial herbs 3-10 dm tall, sometimes suffrutescent. Stems one to several from the base, erect or ascending, profusely branched above; branches 
mostly diverging at angles of $45-60^{\circ}$ from the main stems, upcurved toward the apices, short-pilose to tomentulose throughout. Leaves alternate throughout or the lower opposite, sessile or tapering to a winged petiole up to $1 \mathrm{~cm}$ long; blades linear to oblong or elliptic, $1-6 \mathrm{~cm}$ long, $0.3-2 \mathrm{~cm}$ wide, diminishing toward the inflorescence to linear bracts, 3-nerved from near the base or the narrower leaves with only one prominent vein, apically obtuse to subacute, sometimes mucronate, basally acute to acuminate, entire or less frequently crenate, dentate or serrate, sometimes revolute, on both surfaces densely short-pilose, abaxially punctate-glandular. Branches of the inflorescence leafy-bracteate, distally bearing short-peduncled to subsessile heads in one to several secund, few-headed cymose clusters. Heads ovoid, 5-7 $\mathrm{mm}$ tall and about as broad, often somewhat acutish at the apex. Involucre comprising 35 sterile bracts and the outer row of fertile bracts; involucral bracts and outer receptacular bracts oblong to obovate, $2.2-3.3 \mathrm{~mm}$ long, 0.8-1.2 $\mathrm{mm}$ wide, acute to obtuse, entire to erose-ciliolate, especially distally, greenish below and usually pinkish to purplish above, densely short-pilose with straight, simple, 1-2-celled purplish hairs and punctate-glandular. Flowers 80-140; corollas white to pink or purple, $1.5-2.0 \mathrm{~mm}$ long, tube $0.6-0.8 \mathrm{~mm}$ long, base expanded over the top of the achene, throat abruptly ampliate, 0.6-1.0 $\mathrm{mm}$ long, lobes spreading, triangular, 0.4-0.5 mm long, pubescent externally on the tube and throat and sometimes the lobes with multicellular gland-tipped hairs, hairs at base of tube recurved over apex of achene, lobes minutely papillose within; anthers 0.8-1.0 mm long; stylar base nodular-thickened and papillose, style branches about as long as or longer than the stigmatic area. Achenes blackish oblong, 1.1-1.3 mm long, glabrous, narrowed at base; carpopodium obliquely hemispherical. Chromosome number: $n=10$.

Isocarpha microcephala occurs on lowland sites generally below $300 \mathrm{~m}$ on the coastal plain of southwestern Ecuador and northwestern Peru (fig. 3). In this seasonally dry area I. microcephala grows in grassy areas and disturbed sites. The white to pink (rarely purple) corollas of $1 . m i$ crocephala contrast sharply with the purple-tipped involucral and receptacular bracts. A similar condition occurs in the closely-related I. fistulosa.

Representative specimens. Ecuador. Guayas, Guayaquil, Asplund 16606 (US), Guayaquil, Eggers 14016 (M, US); NE of Guayaquil, Stuessy et al. 4932 (OS); Los Ríos, $3 \mathrm{~km}$ NE of Vinces, Dodson and Thien 1269 (US); Manabi, between La Salina and Chone, Solis 10592 (F). Peru. La Libertad, San Antonio, Ascope, Lopez M. 1270 (US); Lambayeque, Chiclayo-Lambayeque, Sagastegui and Cabanillas 8727 (US); Piura, La Brea, Weberbauer 7763 (F, GH, US); Tumbes, Bosque Nacional de Tumbes, Simpson and Schunke 600 (OS, US).

3. Isocarpha fistulosa Keil \& Stuessy, sp. nov., fig. 4.-TyPE: Ecuador. Loja, Catacocha, 2050 m, 4 Jul 1946, R. Espinosa 599 (holotype: $\mathrm{NY}$ !; isotype: $\mathrm{F}$ !). 


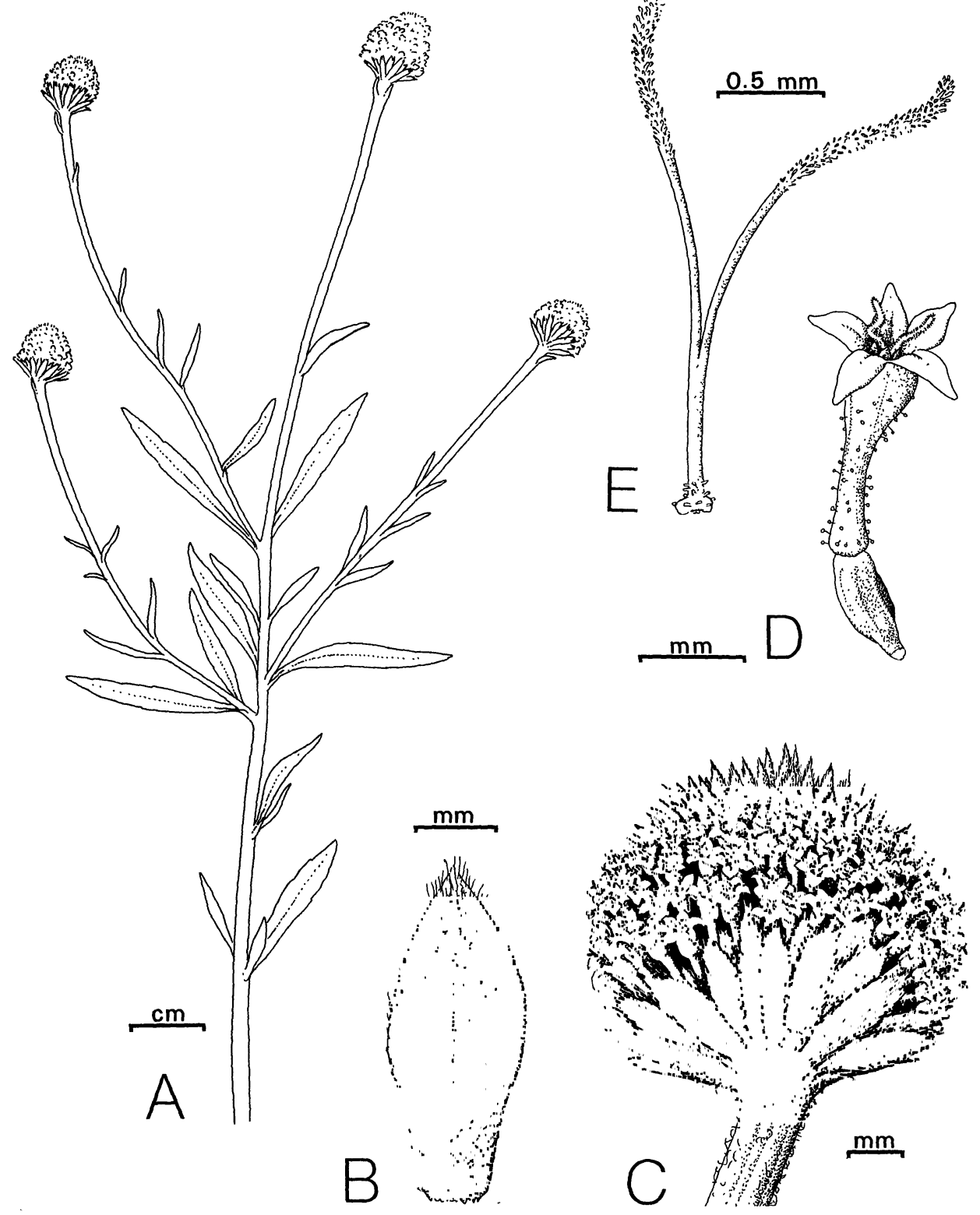

Fig. 4. Isocarpha fistulosa. A. Habit. B. Palea. C. Head. (A-C from Espinosa 599, NY.) D. Floret (Ochoa 1763, US). E. Stigmas and style (Sagastegui and Cabanillas 8546, MO). 
A Isocarpha microcephala (DC.) S. F. Blake pedunculis monocephalis fistulosis et capitulis magnioribus differt.

Erect fibrous-rooted annual herb 2-7 dm tall. Stems solitary or few from the base, erect or ascending, the branches mostly diverging from the main stems at angles of $30-45^{\circ}$, villous to pilose throughout. Leaves opposite below and alternate above, sessile or tapering to a short winged petiole; blades linear to oblong or elliptic, $2-4 \mathrm{~cm}$ long, $0.2-2.2 \mathrm{~cm}$ wide, reduced upward to linear or linear-elliptic bracts, obscurely 3-veined from near the base, apically obtuse to acute, basally acute to acuminate, crenate to serrate or the smaller leaves entire, sometimes revolute, adaxially pilose with elongate multicellular glandular-based trichomes, abaxially densely villous and punctate-glandular. Peduncles terminal and axillary, 2-8 cm long, leafy-bracteate below, naked and fistulose in the terminal $1 / 3$, terminated by solitary heads, sometimes with additional long-peduncled heads arising cymosely from axils of bracts on the primary peduncles. Heads ovoid, 7-10 $\mathrm{mm}$ tall and $6-8 \mathrm{~mm}$ broad. Involucre of 2-4 sterile external bracts and the outermost fertile bracts; involucral bracts oblong to narrowly oblong-obovate, $2.8-3.0 \mathrm{~mm}$ long, 0.7-1.0 $\mathrm{mm}$ wide, in the apical half purplish, in the basal half greenish and inconspicuously 2-keeled, pubescent over the surface and ciliolate with slender straight 1-3-celled hairs. Receptacular bracts about as long as the involucral bracts but narrower and pubescent only near the apex. Florets 120-150; corollas white, 2.3-2.8 mm long, tube narrow, 1.1-1.4 $\mathrm{mm}$ long, throat expanded, 0.7-1.0 mm long, with spreading lobes $0.4-$ $0.5 \mathrm{~mm}$ long and about as wide, pubescent on the tube and sometimes on the throat with multicellular glandular hairs, sometimes sparsely pilose basally with unbranched glandless hairs as well; anthers $0.8-1.0 \mathrm{~mm}$ long; style $2.5-3.0 \mathrm{~mm}$ long, branched from below the middle, bearing a disk-shaped basal node, papillose on and above the node. Achenes blackish, oblong, 1.1-1.4 mm long, glabrous; carpopodium borne obliquely on the base of the achene, not stipitate, white. Chromosome number unknown.

Isocarpha fistulosa grows in southern Ecuador and northwestern Peru (fig. 3) between 1100 and $2200 \mathrm{~m}$. It occurs at higher elevations than the closely related $I$. microcephala and the two species are not known to occur together or to intergrade.

Initially it was believed that this taxon might represent only a new variety within $I$. microcephala, which it closely resembles both morphologically and geographically (fig. 3). In addition to the significant elevational difference (I. fistulosa, 1100-2200 m; I. microcephala, 0-300 m), however, the new taxon differs from I. microcephala in having larger (7$10 \mathrm{~mm}$ vs. 5-7 $\mathrm{mm}$ tall) solitary heads, and distally dilated, fistulose peduncles. The degree of these differences suggests that the new taxon should be recognized as a distinct species rather than just a variety.

Representative specimens. EcUAdor. Loja, village of Zozoranga 
[Sozoranga], Seemann 655 (GH, K). Peru. Piura, Bayando de Ayabaco to Río Quizoz, Ochoa 1763 (US); Huancabampa, near Canchaque, Sagastegui and Cabanillas 8546 (MO).

4. Isocarpha oppositifolia (L.) Cass., Dict. Sci. Nat. 24:19. 1822. Fig. 5.-Most authors have attributed the combination, Isocarpha oppositifolia, to Robert Brown. Although Brown (1817) indicated that he was including Calea oppositifolia (L.) L. within his new genus, Isocarpha, he did not explicitly propose the combination I. oppositifolia. Farr et al. (1979) incorrectly attributed the first use of Isocarpha oppositifolia to Lessing (1832); Cassini (1822) used the combination without attribution to Brown and with reference to Calea oppositifolia (L.) L.

Suffrutescent fibrous-rooted annual or perennial herbs or subshrubs, 3-15 dm tall. Stems one to several from the base, erect or ascending, branches mostly stiffly diverging from main stems at angles of $30-45^{\circ}$, glabrous to densely short-pilose. Leaves opposite below, often alternate above, simple, sessile or petiolate; petioles $1-3(-6) \mathrm{cm}$ long, narrowly to broadly winged; blades linear to oblong-elliptic, lanceolate, or rarely ovate, 1-15 cm long, $0.15-4 \mathrm{~cm}$ wide, 3-nerved from above the base, apically acute or obtuse, basally acute to acuminate, entire or less frequently remotely crenate or dentate, glabrous to densely puberulent on both surfaces, abaxially punctate-glandular. Primary peduncles stout, straight, $2-15 \mathrm{~cm}$ long, naked or remotely bracteate, arising from axils and terminating main stems, one-headed or with dense subcapitate cymose clusters of 2-7 heads terminating the peduncles and arising from axils of bracts. Lower bracts similar in texture to foliage leaves, the upper reduced to linear scales resembling the involucral bracts. Heads ovoid to columnar, 5-15(-20) $\mathrm{mm}$ tall, 4-8 $\mathrm{mm}$ diam., rarely with the head axis forking above. Involucral bracts all subtending florets, oblong, $3.5-5 \mathrm{~mm}$ long, $0.7-1.2 \mathrm{~mm}$ wide, keeled with two slender stramineous ribs that are apically fused and excurrent as a stiff mucro, on either side of the ribs greenish, thin-margined, short-ciliolate with eglandular hairs, over the surface glabrous to densely villous and punctate-glandular. Inner bracts of the receptacle similar to the involucral bracts but stramineous throughout. Florets 60-150; corollas white, 2-3 mm long, tube and throat about equal in length, $0.8-1.3 \mathrm{~mm}$ long, throat gradually ampliate, with the lobes triangular, $0.3-0.5 \mathrm{~mm}$ long, externally pubescent on tube and throat with short glandular hairs, on the inner surface of the lobes smooth; anthers 1.0-1.3 mm long; style nodular-thickened and glabrous below, the papillose appendages equaling or shorter than the stigmatic zone. Achenes blackish, oblong, 1.2-2.2 mm long, glabrous, apically slightly broader than at base; carpopodium slightly oblique, sessile, white, about the same diameter as the achenial base. Chromosome number: $n=10$. 


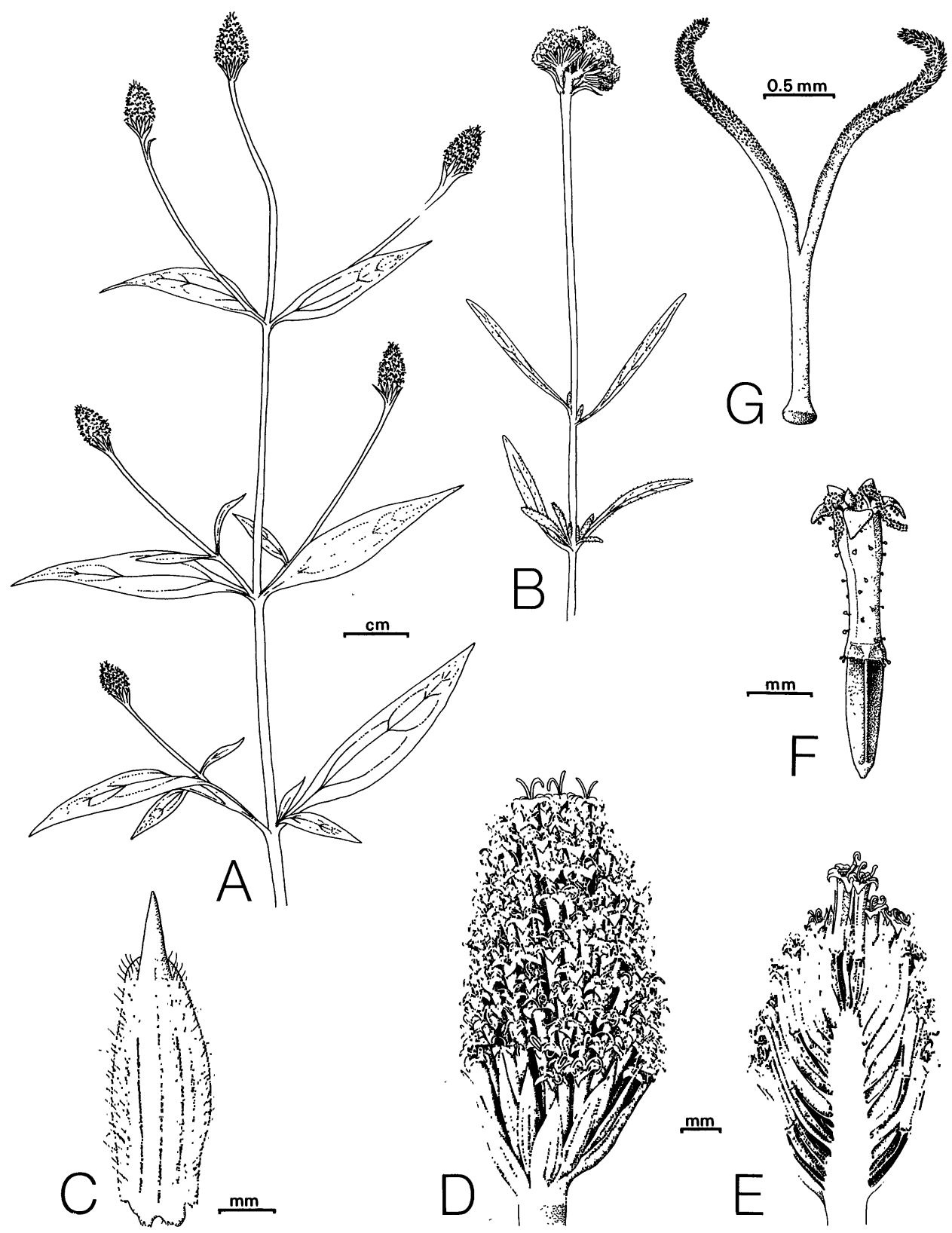

FIG. 5. Isocarpha oppositifolia. A, C-G. Variety achyranthes. B. Variety oppositifolia. A (Palmer 172, UC) and B (Wilson 7809, F). Habit. C. Palea. D and E (longitudinal .section). Heads (same scale). F. Floret. (C-F from Molina 3889, US). G. Stigmas and style (Gaumer 2399, UC). 
Isocarpha oppositifolia is the most widely distributed species in the genus, ranging from southern Texas through Mexico and Central America and into Colombia and Venezuela; the species also is found in the Caribbean from the Bahamas to Jamaica and Trinidad (fig. 6). In parts of its range I. oppositifolia is quite weedy and has benefited from man-made disturbances spreading along roadsides and in other areas where the natural vegetation has been disrupted. Within its broad range two varieties may be distinguished. Most mainland plants are var. achyranthes and most Caribbean plants are var. oppositifolia. In some areas the two races intergrade and assignment of individual plants to variety may be difficult.

4a. IsOcARPHA OPPOSITIFOLIA (L.) Cass. var. oppositifolia-Santolina oppositifolia L., Syst. Nat., 10th ed. 1207. 1759.-Calea oppositifolia (L.) L., Sp. Pl., 2nd ed. 1179. 1763.-[Isocarpha tricephala Cass., Dict. Sci. Nat. 26:280. 1823, nom. superfl-Calydermos jamaicensis Spreng., Syst. Veg. 3:457. 1826, nom. superfl.]-TyPE: Jamaica, P. Browne s.n. (holotype: LINN, IDC microfiche 177. 561.II.6).

Isocarpha angustata Griseb., Flora Brit. W. Ind. 376. 1861.-TyPE: Jamaica, near the cascade of Fall's River, Mar 1850, A. Prior s.n. (holotype: GOET!; isotype: $\mathrm{K}$ !).

Isocarpha glabrata S. F. Blake, Contr. U.S. Natl. Herb 22:614. 1924.Type: Cuba, Camaguey, Silla de Cayo, Cayo Romano, 9-11 Oct 1909, J. A. Shafer 2513 (holotype: US!; isotypes: F! GH! NY!).

Plants herbaceous to subshrubby; stems often woody below, erect to decumbent, mostly less than $5 \mathrm{dm}$ tall, the nodes crowded, internodes mostly $0.5-4 \mathrm{~cm}$ long. Leaves frequently with axillary fascicles; blades linear, narrowly elliptic to oblanceolate, $1-6 \mathrm{~cm}$ long, $0.2-1 \mathrm{~cm}$ wide, usually entire, sometimes revolute, apically obtuse to subacute, basally attenuate to the narrowly winged petiole, on both surfaces glabrous to strigillose, puberulent, or densely velutinous, one or both surfaces punctate-glandular. Primary peduncles $1-15 \mathrm{~cm}$ long, but usually less than 8 $\mathrm{cm}$ long, usually all the peduncles terminated with 2-7 heads congested in cymes, infrequently one-headed. Heads usually less than $10 \mathrm{~mm}$ long at maturity, seldom appearing distinctly columnar. Achenes (1.3-)1.5$2.2 \mathrm{~mm}$ long. Chromosome number unknown.

Isocarpha oppositifolia var. oppositifolia is mostly insular in its distribution, occurring on the Bahamas, Cuba and neighboring islands, and Jamaica (fig. 6). It reaches the mainland in the area around Brownsville (probably introduced), Texas, and in coastal regions of Venezuela. Probably as a result of the discontinuous distribution of this taxon, several localized variants have evolved, differing mainly in leaf morphology and pubescence. Plants from different islands of the Bahamas may differ markedly in appearance. Some plants from Jamaica approach the more widespread var. achyranthes in leaf morphology and the plants in Venezuela apparently intergrade. 


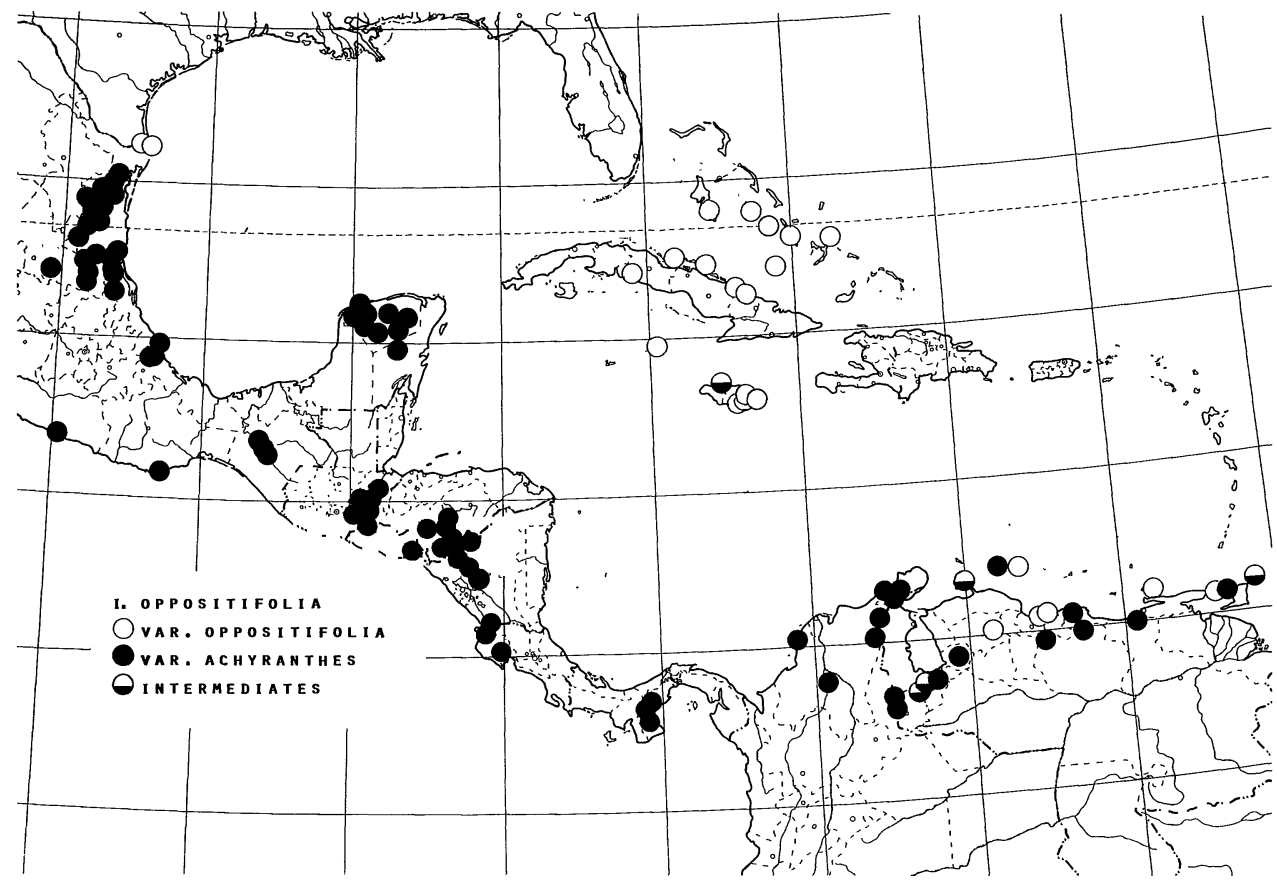

FIG. 6. Distribution of Isocarpha oppositifolia.

Hypotheses can be offered to explain the distribution of var. oppositifolia (fig. 6). One explanation is that this taxon has dispersed across water barriers on more than one occasion. The range of this variety in the Bahamas may represent only a single over-water dispersal event during one of the Pleistocene glacial episodes when the lowering of sea levels in the Caribbean by about $100 \mathrm{~m}$ (Webb 1974) exposed much of the Bahamas as a single land mass separated from Cuba by less than $20 \mathrm{~km}$. However, the deep-water channels between the major islands and the mainland areas preclude a dry-land dispersal route. The mechanism by which the tiny epappose achenes of Isocarpha are transported is not known. Mainland populations of var. achyranthes often occur in swampy areas and shorebirds from such areas may have carried achenes on their feet or feathers to an island location where var. oppositifolia subsequently differentiated. Alternatively, var. oppositifolia may have originated on a coastal mainland site and dispersed to the islands.

Another hypothesis for the distribution of var. oppositifolia (a similar situation exists also with I. atriplicifolia var. wrightii, fig. 2) is vicariance. A recent model of Caribbean biogeography has been presented by Rosen (1976) in which the present islands are postulated as having arisen by northeastward rafting of an ancestral archipelago, "Proto-Antilles," 
which connected North and South American during the late Mesozoic. Ancestral populations of var. oppositifolia could have separated at this time and diverged in isolation from the mainland populations. Whether such a geological scenario actually happened is still controversial among geologists (W. Zinsmeister, pers. comm.). If this did occur and if the dates of occurrence were late enough to have affected the distribution of I. oppositifolia (the entire Compositae are unknown from fossil evidence prior to the Oligocene-Miocene boundary; Raven and Axelrod 1974), then this also could be an alternative explanation for the present pattern of distribution.

Representative specimens. Bahamas. Great Guana Cay, Britton and Millspaugh 2894 (F, GH, NY, US); Great Ragged Island, Wilson 7809 (F, GH, MO, NY). Cayman Islands. Cayman Brac, Kings CB54 (MO, NY). Cuba. Camaguey, Cayo Paredon Grande, Shafer 2742 (F, GH, NY, US); Las Villas, Cayo Frances, Ekman 18566 (A, F, NY); Oriente, Manati Bay, León 16684 (NY). Jamaica. St. Andrew, near Port Royal, Yuncker 17859 (F, MICH, MO); St. Thomas, Four-Mile Woods, Webster and Wilson 4830 (A, MICH). Netherlands Antilles. Bonaire, Boca Spelonk, Arnoldo-Broeders 3708 (A, DUKE, NY). United States. Texas, Cameron Co., on road to Boca Chica from Brownsville, Correll 35497 (ENCB, GH, LL, TEX, UC). Venezuela. Aragua, Ocumare de la Costa, Steyermark 54939 (F, GH, NY, US).

4b. Isocarpha oppositifolia (L.) Cass. var. achyranthes (DC.) Keil \& Stuessy, comb. et stat. nov.-Dunantia achyranthes DC., Prodr. 5:627. 1836.-Lectotype (here chosen): Mexico, Tamaulipas, near Tantoyuca, 1832, J. L. Berlandier 2155 [=2255] (G-DC, IDC microfiche 800. 963.III.1!; isolectotypes: F! GH! MO! P! US! and G-DC, IDC microfiche 800. 963:III.2!). Syntype: Panama, [15 Nov-16 Dec 1790; fide Cutter 1977 in litt.], T. Haenke s.n. (G-DC). The de Candolle herbarium contains two sheets of $D$. achyranthes collected by Berlandier, one bearing the collection data, "Mexique, 1832, Berlandier 2255" and the second "Tantoyuca, 1832, Berlandier 2155." De Candolle cited only number 2155 in the protologue, which combined with the similar appearance of the specimens, suggests that number 2255 is simply a labelling error for 2155 . Further evidence comes from the list of identified Berlandier exsiccatae at $\mathrm{GH}$, which gives 2255 as $\mathrm{Al}$ ternanthera lanuginosa (E. Shaw in litt.).

Plants mostly herbaceous; stems to $15 \mathrm{dm}$ tall, nodes usually well-separated, internodes mostly 5-12 cm long. Leaves seldom with axillary fascicles; blades usually lanceolate to lance-elliptic or ovate, mostly 5-15 $\mathrm{cm}$ long, $1-4 \mathrm{~cm}$ wide, often crenate to serrate, apically acute to acuminate, basally acute or abruptly acuminate onto the winged petiole, puberulent or villous on both surfaces, usually punctate-glandular only on the undersurface. Primary peduncles mostly more than $8 \mathrm{~cm}$ long, 1(5)-headed. Heads at maturity often to $10 \mathrm{~mm}$ long, often appearing 
distinctly columnar. Achenes $1.2-1.9 \mathrm{~mm}$ long. Chromosome number: $n=10$.

Isocarpha oppositifolia var. achyranthes is a wide-ranging and common taxon occurring from northeastern Mexico south to Central America and the northern part of Colombia and Venezuela (fig. 6). It also grows on Trinidad, Tobago, and Curaçao. It occurs mostly in lowland sites, rarely above $700 \mathrm{~m}$ in fields, roadsides, swamps, riverbanks, and assorted disturbed situations. The plants of this variety are quite weedy.

Representative specimens $(*$ = vouchers for chromosome counts reported here). Colombia. Bolivar: Tierrabomba Island, Killip and Smith 14149 (F, GH, NY, US); Guajira, between Carraipia and Calabacito, Cuatrecasas and Castaneda 25505 (US). Costa RicA. Guanacaste, 5-15 km S of La Cruz, Williams et al. 26383 (F, NY, US). El Salvador. La Union, hills behind La Union, Grant 726 (F, MICH). Guatemala. Chiquimula, between Chiquimula and Sta. Rosalia, Molina and Molina 25146 (F, GH, US); Cerro Sillón, Stuessy and Gardner 4376* (OS); Progreso, 2 mi NE of Progreso, White 5110 (DUKE, F, LL, MICH). Honduras. Choluteca, near Morolica, Molina 13043 (LL, NY); El Paraiso, Yuscaran, Williams and Molina 11199 (GH, US); Morazan, between El Llano de las Gallinas and Sta. Lucia, Molina 3889 (US). Mexico. Chiapas, $5 \mathrm{~km} \mathrm{~N}$ of Tuxtla Gutiérrez, Breedlove and Raven 13497 (DS, F, LL, MICH, US); Guerrero, Acapulco and vicinity, Palmer 172 (F, GH, MICH, MO, MSU, NY, UC, US); Oaxaca, Puerto Angel, Morton and Makrinius 2632 (US), Quintana Roo, Chichankanab, Gaumer 2090 (DS, F, GH, MO, US); San Luis Potosí, $0.5 \mathrm{mi} \mathrm{E}$ of El Sabinito, La Duke et al. 589 (OS); Tamaulipas, vicinity of Victoria, Palmer 507 (F, GH, NY, UC, US); 40-60 mi S of Reynosa, Stuessy and Gardner 4014*(OS); 5-10 mi SW of Santander Jiménez, Stuessy and Gardner 4023* (OS); 5-10 mi S of Cd. Victoria, Stuessy and Gardner 4027* (OS); 20-40 mi S of Cd. Victoria, Stuessy and Gardner 4030* (OS), 40-60 mi S of Cd. Victoria, Stuessy and Gardner 4035* (OS); Veracruz, Barranca de Santa María, Purpus 2188 (F, GH, MO, NY, UC); Yucatán, Calotmul, Gaumer 2399 (DS, F, MICH, UC, US); Chichen Itzá, King 6859 (US). Netherlands Antilles: Curaçao, Magdalena, Curran and Haman 8 (CAS, F, GH, NY, UC, US). Nicaragua. Esteli, $0.3 \mathrm{mi} \mathrm{N}$ of $\mathrm{km} 185$ on hwy 1, Jansen and Harriman 551 (OS); Nueva Segovia, $3 \mathrm{~km}$ W of Ocotal, Narvaez 1945 (F, GH, MO, NY, UC). Panama. Herrera, vicinity of Chitre, Allen 1088 (F, GH, US). Trinidad and Tobago. Chacachacare Island, Britton 510 (GH, NY, US). Venezuela. Aragua, vicinity of San Juan de los Moros, Pittier 11353 (GH, NY, US); Trujillo, vicinity of Valera, Pittier 10711 (GH, NY, US).

II. Isocarpha R. Br. sect. Cylindriflorae Keil \& Stuessy, sect. nov.TYPE: Isocarpha megacephala Mattfeld in Pilger.

A sectione Isocarpha tubis brevissimis corollarum cylindracearum aequantibus faucibus diametro, sine nodis stylaris, et abscisis nectariorum cum stylis differt. 
5. Isocarpha MEgacePhala Mattfeld in Pilger, Notizbl. Bot. Gart. BerlinDahlem 9:385. 1927. fig. 7.-Type: Brazil, Bahia, "Sentocé" [Sento Se], Jul 1912, L. Zehntner 1913 (holotype: M!; isotype: B, destroyed; photographs: F! GH! NY! US!).

Herb (perennial?) to more than $5 \mathrm{dm}$ tall. Stems prostrate or decumbent at the base, erect or ascending above, the branches diverging from the main stems at angles of $30-45^{\circ}$, glabrous below the capitulescence, glabrous to sparsely puberulent above. Leaves opposite below and opposite to alternate above, simple, sessile or tapering to a winged petiole; blades oblong-lanceolate, 3-7 cm long, 1-2 $\mathrm{cm}$ broad, reduced upward to linear foliaceous bracts, 3-veined from the base, basally acute to acuminate, apically acute to obtuse, serrulate or the smaller leaves entire, entirely glabrous or bearing a few soft multicellular hairs on the midvein beneath, both surfaces densely punctate-glandular. Peduncles terminal and arising cymosely from the axils of the foliaceous bracts, $1-4 \mathrm{~cm}$ long, in diameter essentially uniform to the base of the head, naked below or bearing one to several foliaceous bracts, in the apical half bracteolate with one or more scale-like bractlets resembling the involucral bracts in size and shape, sparsely glandular-puberulent. Heads ovoid, 12-13 $\mathrm{mm}$ tall and 8-10 mm broad. Involucre of 4-7 sterile external bracts and the outermost floriferous bracts. Involucral bracts ovate, 5.0-5.5 mm long and $2.0-2.5 \mathrm{~mm}$ broad, the outer sterile bracts usually slightly smaller than the floriferous bracts, at the apex acute to acuminate, on the basal half 2-4-keeled, marginally scarious and villous-ciliolate, abaxially glabrous or toward the apex glandular-villosulous. Receptacular bracts about as long as the involucral bracts but gradually diminishing in width with the innermost ca. $0.5 \mathrm{~mm}$ broad, apically acuminate and densely glandular-villosulous. Florets 200-300; corollas white, 2.3-3.0 mm long, cylindrical, throat $1.9-2.4 \mathrm{~mm}$ long, lobes $0.4-0.8 \mathrm{~mm}$ long, with veins extending to the apices of the lobes, externally glabrous, papillose on the adaxial surface and margins of the lobes; anthers 1.4-1.8 $\mathrm{mm}$ long; style ca. 3-4 mm long branched from about the middle, without a basal node but adnate to and deciduous with the nectariferous apex of the achene, glabrous in the unbranched portion. Achenes dark brown, oblong, $2 \mathrm{~mm}$ long, glabrous; carpopodium poorly developed, borne obliquely on the base of the achene and not deciduous with it. Chromosome number unknown.

Isocarpha megacephala is a seldom-collected species known only from the eastern Brasilian states of Bahia, Paraíba, and Pernambuco (fig. 3).

This species is unusual in the genus in several respects: the cylindrical corolla with near-basal stamen insertion; the lack of a basal stylar node and the abscission of the achenial nectary with the corolla and with the stylar base; and the papillose corolla lobes that are veined to the apex. This suite of unique features is an indication that Isocarpha megacephala has substantially differentiated evolutionarily from the remaining species of the genus. 

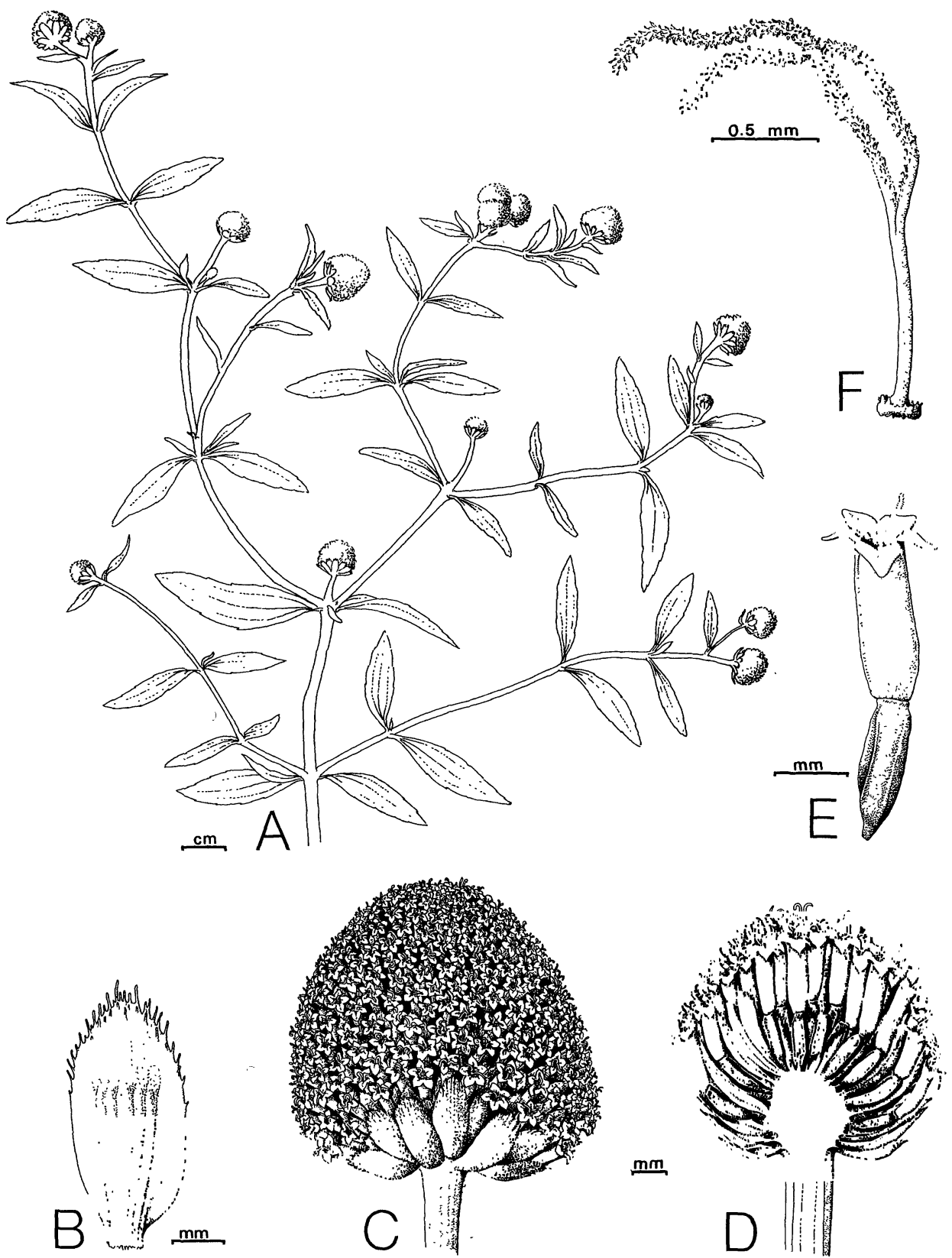

FIG. 7. Isocarpha megacephala (Pickel 05B, SP). A. Habit. B. Palea. C and D (longitudinal section). Heads (same scale). E. Floret. F. Stigmas and style. 
Representative specimens. Brazil. Paraíba, Sousa, Seccas 25 (US); Caruarú, Pickel 05B (SP).

\section{Doubtful and Excluded Taxa}

Isocarpha Less. in Schlecht. \& Cham., Linnaea 5:141. 1830, non R. Br. 1817.-TYPE: Isocarpha echioides Less. in Schlecht. \& Cham. =AGERatum Echioides (Less. in Schlecht. \& Cham.) Hemsl., fide Johnson (1971).

Isocarpha amellus Spreng. ex DC., Prodr. 5:493. 1836, nom. nud., as synonym of Salmea scandens (DC.) DC.

Isocarpha berterii Balb. ex DC., Prodr. 5:140. 1836, nom. nud., as synonym of Critonia dalea (L.) DC.

Isocarpha echioides Less. in Schlecht. \& Cham., Linnaea 5:151. 1830.— Type: Mexico, Veracruz, "in graminosis prope Hacienda de la Laguna," C. J. W. Schiede 304 (holotype: B, destroyed during WW II; photograph: GH!). =AgERATUm ECHioides (Less. in Schlecht. \& Cham.) Hemsl., fide Johnson (1971).

Isocarpha eupatorioides Gardn., London J. Bot. 5:456. 1846.—TYPE: Brazil, Minas Gerais, near São Ramão, Jul 1840, G. Gardner 4839 (holotype: BM!; photograph: OS!; isotypes: NY, 3!). Baker (1876) transferred I. eupatorioides to Trichogonia, reduced it to varietal status, and renamed it as T. salviifolia Gardn. var. calva Baker. Mattfeld (1923) transferred the taxon to T. menthifolia Gardn. as var. calva (Baker) Mattf. King and Robinson (1980c), apparently unaware that I. eupatorioides and $T$. menthifolia var. calva were based on the same type, published the new combination Trichogonia eupatorioides (Gardn.) King \& Robinson. We have compared material of Trichogonia menthifolia at US with the types of Isocarpha eupatorioides and they appear to be conspecific.

Isocarpha fastigiata Gardn., London J. Bot. 5:455. 1846.-TyPE: Brazil, Minas Gerais, Diamond District, Jul 1842, G. Gardner 4837 (holotype: BM!; photograph: OS!; isotypes: F! NY, 2!). 三Ageratum FasTigiatum (Gardn.) King \& Robinson.

Isocarpha foliosa Gardn., London J. Bot. 5:457. 1846.—TyPE: Brazil, Minas Gerais, near São Romão, Jun 1840, G. Gardner 4838 (holotype: BM!; photograph: OS!; isotype: NY!). B. L. Robinson (1913) treated I. foliosa as belonging to Alomia. King and Robinson (1980d) have recently used this species as the basis for a new monotypic genus: Teixeiranthus foliosus (Gardn.) King \& Robinson.

Isocarpha kunthii Cass., Dict. Sci. Nat. 24:19. 1822, nom. superfl., based on type of Spilanthes leucantha H.B.K.

Isocarpha pyrethraria (L.) Cass., Dict. Sci. Nat. 26:280. 1823.—Cotula pyrethraria L., Mant. Pl. 116. 1767.-TyPE: “America," locality, date, and collector unknown (LINN, IDC microfiche 177. 554:I.1!) $\equiv$ SPILANTHeS oleracea L. (fide Robert Jansen pers. comm.), a taxon 
that will be treated as a member of the genus Acmella A. Rich. in a forthcoming revision (Jansen in prep.).

Acknowledgments. Special thanks go to: the curators of the following herbaria from which loans of specimens were made (A, BM, CAS, DS, DUKE, ENCB, F, GH, GOET, LL, M, MEXU, MICH, MO, MSU, NY, SP, TEX, UC, US); Robert M. King and Harold Robinson (Smithsonian Institution) for discussions on various aspects of the systematics of the Eupatorieae and for making available for examination the holotype of Isocarpha megacephala, which they had borrowed from M; R. A. Popham and V. Raghavan of Ohio State University for comments on developmental patterns of floral and vegetative structures; Elizabeth Shaw of the Gray Herbarium for help with information on Berlandier exsiccatae; Donald Cutter of the University of New Mexico for more precise dates of the Malaspina expedition; Ho-Yih Liu for anatomical help; David Dennis for drawing figures 4, 5, and 7; Vicki Funk, Robert Jansen, and Roger Sanders for helpful discussions and for critically reading portions of the manuscript; Ohio State University College of Biological Sciences Grantin-Aid for a visit to London and Paris by T.F.S. to examine type material; and NSF Grant DEB 75-70819 for field studies by T.F.S. and a research visit by D.J.K. to Ohio State in the summer of 1980.

\section{Literature Cited}

Alain, H. 1963. Compositae, Pp. 175-313 in Flora de Cuba, vol. 5. Univ. Puerto Rico, Río Piedras: Editorial Universitaria.

Aristeguieta, L. 1964. Compositae. Part 2 of Flora de Venezuela, vol. 10, ed. T. Lasser. Caracas: Instituto Botánico.

Baker, J. G. 1876. Compositae. Pp. 181-376 in Flora Brasiliensis, part 2, ed. C. F. P. von Martius. Stuttgart.

Bentham, G. and J. D. Hooker. 1873. Compositae. Pp. 163-533 in Genera plantarum, vol. 2, part 1. London: Reeve \& Co.

Blake, S.F. 1926. New names for five American Asteraceae. Proc. Biol. Soc. Wash. 39:144.

Bohlmann, F., P. K. Mahanta, A. A. Natu, R. M. King, and H. Robinson. 1978. New germacranolides from Isocarpha species. Phytochemistry 17:471-474.

- C. Zdero, R. M. King, and H. Robinson. 1977. A new ageratone derivative from Isocarpha oppositifolia. Phytochemistry 16:768.

Briquet, J. 1917. Le critère différentiel des bractées involucrales et paléales dans la calathide des Composées. Arch. Sci. Phys. Nat., ser. 4. 43:1-5.

Brown, R. 1817. Observations on the natural family of plants called Compositae. Trans. Linn. Soc. London 12:75-142.

CAndolle, A. P. DE. 1836. Compositae. Part I of Prodromus systematis naturalis regni vegetabilis, vol. 5. Paris: Treuttèl et Würtz.

Carlquist, S. 1976. Tribal interrelationships and phylogeny of the Asteraceae. Aliso 8:465-492.

Cassini, H. 1822. Isocarphe. Pp. 18-20 in Dictionnaire des Sciences Naturelles, 2nd ed., vol. 24, ed. F. Cuvier. Paris.

1823. Lidbeckie. Pp. 275-286 in Dictionnaire des Sciences Naturelles, 2nd ed., vol. 26, ed. F. Cuvier. Paris.

Groneuist, A. 1955. Phylogeny and taxonomy of the Compositae. Amer. Midl. Naturalist 53:478-511. 1977. The Compositae revisited. Brittonia 29:137-153.

Cutter, D. C. 1977. Malaspina's grand expedition. Pp. 28-41 in The Malaspina expedition. Santa Fe: Mus. New Mexico Press.

FARr, E. R., J. A. Leussink, and F. A. StAfleu, eds. 1979. Index nominum genericorum (plantarum). Utrecht: Bohn, Scheltema \& Holkema. 
Gardner, G. 1846. Contributions towards a Flora of Brazil, being the characters of several new species of Compositae, belonging to the tribe Eupatoriaceae. Lond. J. Bot. 5:455-491.

GrisebaCH, A. H. R. 1860. Flora of the British West Indian Islands, vol. 3. London: Reeve \& Co.

Hemsley, W. B. 1881. Biologia Centrali-americana, Botany, vol. 2. London: R. H. Porter and Dulau \& Co.

Hoffmann, O. 1890. Compositae. Pp. 87-387 in Die natürlichen Pflanzenfamilien, vol. 4, part 5, eds. A. Engler and K. Prantl. Leipzig: W. Engelmann.

Jansen, R. K. 1979. The generic relationships of Spilanthes (Compositae: Heliantheae). Bot. Soc. Amer., Misc. Ser. Publ. 157:60 (abstr.).

1981. Systematics of Spilanthes (Compositae: Helianthae). Syst Bot. 6:231-257. and T. F. Stuessy. 1980. Chromosome counts of Compositae from Latin America. Amer. J. Bot. 67:585-594.

Johnson, M. F. 1971. A monograph of the genus Ageratum L. (Compositae-Eupatorieae). Ann. Missouri Bot. Gard. 58:6-88.

King, R. M., D. W. Kyhos, A. M. Powell, P. H. Raven, and H. Robinson. 1976. Chromosome numbers in Compositae, XIII. Eupatorieae. Ann. Missouri Bot. Gard. 63:862-888.

- and H. Robinson. 1969. Studies in the Compositae-Eupatorieae, XI. Typification of genera. Sida 3:329-342.

and -1970 . The new synantherology. Taxon 19:6-11.

and . 1975. Compositae, Eupatorieae. Pp. 888-1004 in Flora of Panama ed. W. G. D'Arcy. Ann. Missouri Bot. Gard. 62.

and -1980 a. Studies in the Eupatorieae (Asteraceae). CXCII. Validation of subtribes. Phytologia 46:446-450.

and $\longrightarrow$ 1980b. Studies in the Eupatorieae (Asteraceae). CXCIV. A new genus Parapiqueria. Phytologia 47:110-111.

and $\longrightarrow$. 1980c. Studies in the Eupatorieae (Asteraceae). CLXXXVII. Additions to Trichogonia and Trichogoniopsis. Phytologia 45:105-123.

and $1980 \mathrm{~d}$. Studies in the Eupatorieae (Asteraceae). CXCIII. A new genus, Teixeiranthus. Phytologia 47:108-109.

Lessing, C. F. 1830. Synanthereae Rich. [Pp. 128-164 in D. F. L. von Schlechtendal and L. A. von Chamisso, Plantarum Mexicanarum a cel. viris Schiede et Deppe collectarum recensio brevis.] Linnaea 5:72-174, 206-236, 554-625.

1831. Synanthereae Rich. [Pp. 397-411 in D. F. L. von Schlechtendal and L. A. von Chamisso, Plantarum Mexicanarum a cel. viris Schiede et Deppe collectarum recensio brevis.] Linnaea 6:385-430.

1832. Synopsis generum Compositarum. Berlin: Dunckeri et Humblotii.

Mattfeld, J. 1923. Compositae. [Pp. 428-451 in Plantae Lützelburgianae brasilienses I, ed. R. Pilger.] Notizbl. Bot. Gart. Berlin-Dahlem 8:425-451.

Philipson, W. R. 1947. Studies in the development of the inflorescence II. The capitula of Succisa pratensis and Dipsacus fullonum L. Ann. Bot. (London) N. S. 11:285298.

1948. Studies in the development of the inflorescence IV. The capitula of Hieracium boreale Fries and Dahlia gracilis Ortg. Ann. Bot. (London) N. S. 12:65-75. 1953. The relationships of the Compositae particularly as illustrated by the morphology of the inflorescence in the Rubiales and the Campanulatae. Phytomorphology 3:391-404.

Raven, P. H. and D. I. Axelrod. 1974. Angiosperm biogeography and past continental movements. Ann. Missouri Bot. Gard. 61:539-673.

Robinson, B. L. 1911. On some hitherto undescribed or misplaced Compositae. Proc. Amer. Acad. Arts 47:206-216.

1913. Revisions of Alomia, Ageratum, and Oxylobus. Proc. Amer. Acad. Arts 49:438-491. 
Robinson, H. and R. M. King. 1977. Eupatorieae-systematic review. Pp. 437-485 in The biology and chemistry of the Compositae, eds. V. H. Heywood et al. London: Academic Press.

Rosen, D. E. 1976. A vicariance model of Caribbean biogeography. Syst. Zool. 24:431464.

Stafleu, F. A. and R. S. Cowan. 1976. Taxonomic literature, 2nd ed., vol. 1. Utrecht: Bohn, Scheltema \& Holkema.

Stebbins, G. L. 1967. Adaptive radiation and trends of evolution in higher plants. Pp. 101-142 in Evolutionary biology, vol. 1, eds. T. Dobzhansky et al. N.Y.: AppletonCentury-Crofts.

Stuessy, T. F. 1977. Heliantheae-systematic review. Pp. 621-671 in The biology and chemistry of the Compositae, eds. V. H. Heywood et al. London: Academic Press.

WAGEnitz, G. 1976. Systematics and phylogeny of the Compositae (Asteraceae). Plant Syst. Evol. 125:29-46.

WebB, S. D. 1974. Pleistocene mammals of Florida. Gainesville: Univ. Florida Press.

Note added in proof. Pregill (1981. Syst. Zool. 30:147-155) argues strongly against the "Proto-Antilles" concept of Caribbean biogeography proposed by Rosen (1976). This strengthens the over-water dispersal hypothesis for distributions of varieties of Isocarpha atriplicifolia and $I$. oppositifolia. See also the recent paper by Carlquist (1981. Amer. Sci. 69:509-516) for a good discussion of probability of chance dispersal events. 